\title{
MENINGKATKAN KEMAMPUAN MEMBACA TEKS DESKRIPSI SEDERHANA PADA SISWA KELAS I SEMESTER II SD N 9 PEGUYANGAN \\ MELALUI PENERAPAN PEMBELAJARAN STUDENT TEAMS ACHIEVEMENT DIVISIONS (STAD) BERBANTUAN MEDIA GAMBAR
}

\author{
Ni Nyoman Wardani \\ SDN 9 Peguyangan \\ agusb1474@gmail.com
}

\begin{abstract}
ABSTRAK
Jenis penelitian ini adalah Penelitian Tindakan Kelas (PTK). PTK ini bertujuan untuk mendeskripsikan penerapan pembelajaran Student Teams Achievement Divisions (STAD) berbantuan media Gambar dapat meningkatkan kemampuan membaca siswa. Subyek penelitian ini adalah siswa kelas 1 SDN 9 Peguyangan Kecamatan Denpasar Utara Kota Denpasar Tahun Ajaran 2018/2019 pada Semester II dengan jumlah siswa 23 orang, yang terdiri dari 14 orang siswa Laki-laki dan 9 orang siswa perempuan. Teknik pengumpulan data yang digunakan dalam penelitian ini adalah studi observasi, wawancara dan tes. Penelitian ini menggunakan dua siklus, setiap siklus dalam penelitian tindakan kelas ini terdiri dari empat tahapan penting yaitu rencana, tindakan, observasi, dan refleksi. Hipotesis dibuktikan menggunakan teknik analisis kuantitatif yakni analisis statistik deskriptif. Analisis dilakukan dengan program Microsoft Excel.

Hasil penelitian menunjukkan bahwa aktivitas/sikap siswa selama mengikuti kegiatan belajar mengajar di kelas Pada siklus I dan siklus II berada pada kriteria baik dan Hasil evaluasi pembelajaran kemampuan siswa dalam membaca teks deskripsi sederhana melalui penerapan pembelajaran STAD berbantuan media gambar pada siklus I diperoleh nilai rata-rata klasikal 70,29 ketuntasan $74 \%$, dan nilai rata-rata klasikal pada siklus II adalah 73,41 ketuntasan $83 \%$. Hal ini bermakna bahwa penerapan pembelajaran STAD berbantuan media gambar dapat meningkatkan kemampuan membaca teks deskripsi sederhana siswa kelas I Semester II SD Negeri 9 Peguyangan.
\end{abstract}

Kata kunci: STAD, Media Gambar, Membaca Teks Deskripsi

\section{PENDAHULUAN}


Buku adalah jendela dunia, dan membaca adalah kuncinya. Membaca dapat memperluas pengetahuan, wawasan, dan pengalaman setiap orang. Hal ini yang menjadikan membaca sebagai fondasi dasar pada keterampilan Akademik.

Pramana (2009) mengungkapkan membaca adalah tahap penting dalam proses perkembangan anak karena membaca merupakan gerbang pertama menuju proses pembelajaran yang lebih kompleks. Sedangkan menurut Alfiah (2014) manusia yang gemar membaca mendapat pengetahuan dan wawasan baru yang akan semakin meningkatkan kecerdasan, sehingga mereka akan mampu menghadapi tantangan hidup pada masa-masa mendatang. Bagi siswa kelas I Sekolah Dasar, kemampuan membaca yang diajarkan kepada siswa adalah membaca teks deskripsi sederhana. Membaca teks deskripsi sederhana merupakan membaca permulaan bagi siswa untuk mengenal dan memahami rangkaian huruf dan kata-kata. Disinilah guru harus pandai menentukan strategi yang tepat dalam penerapan sistem pembelajaran agar dapat menumbuhkan gairah belajar siswa.

Proses mengajar di tingkat sekolah dasar pada umumnya cenderung bersifat konvensional. Menurut Djamarah (1996) Pembelajaran Konvensional adalah metode pembelajaran tradisional/ceramah dimana pembelajaran terpusat pada guru sebagai pemberi informasi, dan komunikasi cenderung satu arah dari guru kepada siswa, proses pembelajaran yang terjadi hanya sebatas pada penyampaian informasi, sehingga peran guru masih sangat menonjol. Implikasinya adalah siswa menjadi pasif yaitu lebih banyak mendengarkan penjelasan guru di depan kelas dan hanya melaksanakan tugas jika guru memberi soal-soal latihan.

Sebagai bahan kajian yang bersifat praktis, peneliti sekaligus bertindak sebagai Guru kelas 1 SD Negeri 9 Peguyangan memberikan evaluasi awal melalui tes membaca, dan menjawab beberapa soal pada muatan materi Bahasa Indonesia. Hasil evaluasi awal menunjukkan kemampuan membaca siswa ternyata masih banyak yang lafal atau intonasinya ada pengaruh dari bahasa daerah. Selain itu, ketepatan pengucapan masih jauh dari sasaran dan volume suara kadang-kadang tidak kedengaran dan tidak jelas. Nilai ratarata siswa hanya mencapai 67,61 (Lampiran 2) dengan ketuntasan 61\% (KKM = 67) yang menggambarkan bahwa kemampuan membaca siswa kelas 1 SD Negeri 9 Peguyangan belum optimal dan perlu di tingkatkan. Kekurang mampuan membaca pada siswa akan mempunyai dampak terhadap pencapaian hasil belajar tidak saja terhadap hasil belajar 
dalam muatan materi Bahasa Indonesia, tetapi juga akan berdampak pada muatan materi pelajaran yang lainnya. Dengan demikian dipandang perlu untuk melakukan perbaikan dalam metode pembelajaran berikutnya agar kemampuan membaca siswa secara keseluruhan dapat meningkat. Sudah seharusnya seorang guru lebih kreatif dalam upaya memaksimalkan proses pembelajaran, baik itu dari segi materi, metode maupun media yang digunakan agar dapat membangkitkan minat siswa agar lebih giat belajar di sekolah.

Pada penelitian ini, untuk meningkatkan kemampuan membaca teks deskripsi sederhana dilakukan dengan menerapkan pembelajaran Student Teams Achievement Divisions (STAD) berbantuan media Gambar. Pembelajaran tipe STAD mengarahkan siswa untuk belajar bekerja sama dalam suatu kelompok belajar, dan setiap anggota kelompok dapat saling memberi masukan pada prestasi kelompok sehingga setiap siswa akan mendapat kesempatan untuk bersosialisasi dengan teman-temannya untuk mencapai hasil yang maksimal. Sedangkan Media gambar berfungsi sebagai pendukung sarana belajar yang dapat merangsang minat serta perhatian siswa sehingga membantu siswa dalam memahami dan mengingat isi informasi. Siswa dapat melihat secara langsung gambar yang akan dijadikan objek untuk dideskripsikan, sehingga siswa memperoleh kemudahan untuk mendeskripsikan objek tersebut. Hal inilah yang mendorong dan memotivasi penulis untuk melakukan penelitian tindakan kelas dengan memilih topik "Meningkatkan Kemampuan Membaca Teks Deskripsi Sederhana Pada Siswa Kelas I Semester II SD Negeri 9 Peguyangan melalui penerapan Pembelajaran Student Teams Achievement Divisions (STAD) berbantuan Media Gambar".

\section{KAJIAN PUSTAKA}

\section{Pembelajaran Bahasa Indonesia Tingkat Sekolah Dasar}

Pembelajaran bahasa Indonesia di sekolah dasar merupakan pembelajaran yang paling utama, terutama di SD kelas rendah (I, II, dan III). Melalui pelajaran Bahasa, siswa dapat menimba ilmu pengetahuan, teknologi, dan seni, serta informasi yang ditularkan dari guru. Guru sebagai pelaksana dan pengelola pembelajaran di sekolah harus dapat merancang, melaksanakan, dan mengevaluasi aspek-aspek yang tercakup dalam pembelajaran bahasa Indonesia. Untuk memaksimalkan hasil belajar bahasa Indonesia, maka pembelajaran bahasa Indonesia dikembangkan melalui empat aspek yaitu menyimak, berbicara, membaca, dan menulis (Santosa, 2008: 3.17). 


\section{Hakikat Kemampuan Membaca}

\section{1) Pengertian Kemampuan (ability)}

Chaplin (1997:34) menyatakan Kemampuan atau ability (kemampuan, kecakapan, ketangkasan, bakat, kesanggupan) merupakan tenaga (daya kekuatan) untuk melakukan suatu perbuatan. Sedangkan menurut Robbins (2001:38) kemampuan diartikan sebagai kesanggupan bawaan sejak lahir atau merupakan hasil latihan atau praktek.

\section{2) Pengertian Membaca}

Membaca artinya melihat serta memahami isi dari apa yang tertulis. Mulyati (1998:5) menyatakan bahwa membaca adalah suatu proses mengolah bacaan secara kritis kreatif yang dilakukan dengan tujuan untuk memperoleh pemahaman yang bersifat menyeluruh dan mendalam tentang isi bacaan. Dalam kegiatan membaca, pembaca memproses informasi dari teks yang dibaca untuk memperoleh makna. Membaca tidak hanya mata yang berperan sebagai alat untuk mengamati, tetapi juga hati dan pikiran turut menentukan keberhasilan membaca. Membaca juga hendaknya mempunyai tujuan, karena seorang yang membaca dengan suatu tujuan, cenderung lebih memahami dibandingkan dengan orang yang tidak mempunyai tujuan. Dengan demikian, kegiatan membaca tidak hanya melihat tulisan, tetapi juga harus mampu memahami dan mengerti bahkan harus bisa menyampaikan kembali pesan baik secara lisan maupun secara tertulis.

\section{3) Pengertian Membaca Teks Deskripsi Sederhana}

Soeparno (2007:1.11) menyatakan bahwa deskripsi adalah tulisan yang ditulis untuk melukiskan atau menggambarkan suatu objek sehingga pembaca seolah-olah menyaksikan dan mengalaminya sendiri. Menurut Rukayah (2004: 14) siswa dikatakan berkemampuan membaca jika dia dapat membaca dengan lafal dan intonasi yang jelas, benar dan wajar, serta lancar dalam membaca dan memperhatikan tanda baca. Di dalam pembelajaran membaca teks deskripsi sederhana, siswa dituntut untuk dapat menyuarakan huruf, suku kata, kata dan kalimat yang disajikan dalam bentuk tulisan ke dalam bentuk lisan (Sabarti Akhadiah, dkk. 1993: 11).

\section{Hakikat Pembelajaran Kooperatif tipe Student Teams Achievement Divisions (STAD)}

Pembelajaran kooperatif adalah suatu strategi pembelajaran dimana siswa belajar dan bekerja dalam kelompok-kelompok kecil secara kolaboratif yang anggotanya terdiri dari 2 sampai 5 orang, dengan struktur kelompoknya yang bersifat heterongen. Dalam 
proses pembelajaran guru berperan sebagai fasilitator harus memahami teori-teori belajar, dan teknik-teknik pembelajaran.

Dalam penelitian tindakan kelas ini metode pembelajaran kooperatif yang digunakan adalah Pembelajaran Student Teams Achievement Divisions (STAD). STAD dikembangkan oleh Robert Slavin dan kawan-kawan dari Universitas John Hopkins. Pembelajaran tipe ini dipandang paling sederhana dan paling langsung dari pendekatan pembelajaran kooperatif. Para guru menggunakan Pembelajaran tipe STAD untuk mengajarkan informasi akademik baru kepada siswa setiap minggu, baik melalui penyajian verbal maupun tertulis.

\section{Media Gambar}

Ketepatan dalam pemilihan media akan sangat berpengaruh terhadap pencapaian tujuan pembelajaran. Pemilihan media tersebut didasarkan pada tingkat perkembangan kognitif siswa.

Penggunaan media dalam pembelajaran hendaknya disesuaikan dengan tingkat perkembangan siswa. Siswa SD berada pada tahap perkembangan operasional konkret, sehingga media yang digunakan berupa media konkret yaitu dapat berupa media gambar. Media gambar dapat meningkatkan motivasi siswa dalam pembelajaran dan dapat merangsang minat serta perhatian siswa sehingga membantu siswa dalam memahami dan mengingat isi informasi pembelajaran. Media gambar termasuk media grafis atau visual yang berfungi untuk menyalurkan pesan dari sumber ke penerima pesan melalui indera penglihatan. Pesan yang disampaikan dituangkan ke dalam simbol-simbol komunikasi visual (Sadiman, 2011:28).

\section{Kerangka Berpikir}

Kerangka berpikir merupakan hasil abstraksi dari kerangka teori yang dikaitkan dengan masalah penelitian yang dihadapi. Pada penelitian ini, guru menerapkan pembelajaran STAD berbantuan media Gambar yang akan mendorong siswa untuk lebih aktif belajar, baik secara mental, intelektual, fisik maupun sosial, dengan harapan kemampuan membaca teks deskripsi sederhana siswa kelas I SD Negeri 9 Peguyangan akan meningkat.

Student Team Achievement Divisions (STAD) adalah suatu metode pembelajaran dimana siswa belajar untuk bekerja sama dalam suatu kelompok, dan setiap anggota kelompok dapat saling berinteraksi satu sama lain. Media Gambar yang digunakan 
tentunya dapat menarik minat dan perhatian siswa. Dengan demikian penerapan pembelajaran ini akan memancing kreatifitas siswa, tanggung jawab siswa, kekompakan siswa, sehingga akan lebih inovatif dan bergairah dalam proses belajar.

Aktifitas membaca yang diperoleh siswa pada pembelajaran ini akan sangat berpengaruh terhadap pembelajaran membaca selanjutnya di kelas tinggi. Jadi, dalam proses pembelajaran tersebut guru diharapkan selalu menerapkan pendekatan edukatif dan metode yang tepat bukan sekedar hanya mengajarkan materi pelajaran, sejumlah fakta dan informasi. Kebosanan yang dialami oleh siswa tentunya akan berpengaruh pada aktivitas belajar siswa dan secara tidak langsung juga akan mempengaruhi ketuntasan belajar.

Penulis berharap penerapan Pembelajaran STAD berbantuan media gambar ini memberikan hasil yang optimal dan dapat meningkatkan kemampuan siswa dalam hal membaca teks deskripsi sederhana. Penelitian ini merupakan penelitian tindakan kelas melalui proses atau siklus berulang, bertahap, dan berkelanjutan yang pelaksanaannya direncanakan melalui dua siklus. Setiap siklus meliputi empat tahapan yakni perencanaan, pelaksanaan, observasi, dan refleksi.

Hipotesis dalam penelitian ini di hitung menggunakan teknik analisis kuantitatif. Analisis ini meliputi analisis statistik deskriptif. Analisis dilakukan dengan menggunakan alat bantu komputer yaitu program Microsoft Excel.

\section{Hipotesis Penelitian}

Berdasarkan kajian teori dan kerangka berpikir di atas maka diajukan hipotesis, yaitu: Semakin baik pembelajaran yang dilakukan dengan Penerapan Student Teams Achievement Divisions (STAD) berbantuan media Gambar, maka kemampuan membaca Teks Deskripsi Sederhana siswa kelas 1 Semester II SD Negeri 9 Peguyangan Tajun Ajaran 2018/2019 akan meningkat.

\section{III.METODOLOGI PENELITIAN}

Lokasi penelitian ini adalah di Sekolah Dasar Negeri 9 Peguyangan yang beralamat di Jl. Cekomaria No. 1 Denpasar Kecamatan Denpasar Utara. Penelitian ini dilaksanakan pada Semester II yaitu pada tanggal 20 Januari 2019 sampai dengan tanggal 9 Juni 2019.

Subyek penelitian ini adalah siswa kelas 1 SDN 9 Peguyangan Kecamatan Denpasar Timur Kota Denpasar Tahun Ajaran 2018/2019 pada Semester II dengan jumlah siswa 23 orang, yang terdiri dari 14 orang siswa Laki-laki dan 9 orang siswa perempuan. 
Teknik pengumpulan data yang digunakan dalam penelitian ini adalah studi observasi, wawancara dan tes. Prosedur penelitian ini melalui 2 tahapan atau siklus yang setiap siklus berisi empat langkah yaitu: tahap perencanaan, tahap pelaksanaan, tahap observasi/ealuasi dan tahap refleksi. Hipotesis dibuktikan menggunakan teknik analisis kuantitatif yakni analisis statistik deskriptif. Analisis dilakukan dengan program Microsoft Excel.

Tolok ukur keberhasilan penelitian ini adalah: Aktivitas siswa sekurang-kurangnya dengan kriteria baik, Siswa dikatakan berkemampuan membaca jika nilai rata-rata hasil belajar siswa Kelas I SDN 9 Peguyangan minimal $\geq 70,00$. Siswa dinyatakan tuntas belajar apabila $80 \%$ siswa memenuhi $\mathrm{KKM} \geq 67$.

\section{HASIL PENELITIAN DAN PEMBAHASAN}

Hasil observasi pada siklus I dapat dideskripsikan bahwa masih ada siswa yang kurang fokus dan asyik berbicara dan bermain menggunakan media pembelajaran. Pada kegiatan diskusi kelompok, kegiatan masih didominasi oleh siswa yang pandai sedang siswa yang lain hanya mengikuti saja.

Nilai rata-rata siswa secara klasikal pada siklus I adalah 70,29. Ketuntasan yang mampu dicapai sebesar $74 \%$. Hal ini bermakna bahwa $26 \%$ siswa belum tuntas dan pembelajaran pada siklus I belum mencapai target ketuntasan yang diharapkan sehingga harus dioptimalkan pada Siklus II.

Fokus pembelajaran Tematik diarahkan kepada pembahasan tema-tema yang paling dekat dengan kehidupan siswa, karena pemisahan mata pelajaran tidak begitu jelas. Dalam penelitian ini di tekankan pada muatan materi bahasa Indonesia dengan kompetensi dasar yakni mengenal dan mengamati teks deskripsi sederhana tentang anggota tubuh dan panca indra.

Kemudian setelah dilakukan perbaikan pada siklus 2 dapat dideskripsikan bahwa kendala yang ditemui pada sikus I telah dapat di atasi. Siswa tampak memperhatikan penjelasan guru dengan sungguh-sungguh. Siswa yang asyik bercerita dengan temannya diberikan peringatan oleh guru sehingga keadaan kembali kondusif. Siswa memiliki antusias yang tinggi ketika guru menyajikan materi dengan menunjukkan gambar. Siswa mengerjakan tugas kelompok dengan tertib. Namun, saat menyimak presentasi hasil kerja kelompok lain, siswa tidak memberi tanggapan dan masukan terhadap hasil kerja 
kelompok lain. secara umum siswa dapat dengan baik menyimpulkan materi yang telah dipelajari bersama-sama dengan guru di akhir kegiatan.

Berikut ini disajikan Grafik hasil evaluasi belajar siswa dalam Muatan Materi Bahasa Indonesia (Kemampuan Membaca Teks Deskripsi) mulai dari sebelum dilakukannya penelitian tindakan sampai pada setelah penelitian tindakan kelas melalui dua siklus dengan penerapan pembelajaran STAD berbantuan media Gambar, yakni sebagai berikut:

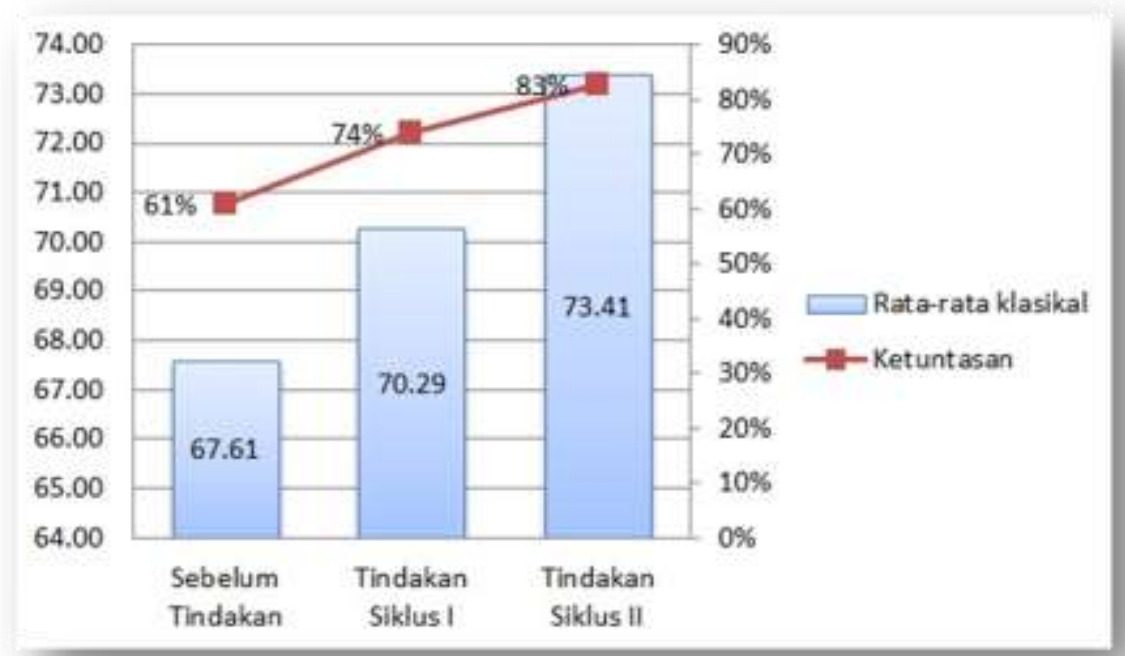

\section{Gambar 4.1}

\section{Grafik hasil evaluasi Kemampuan Membaca Teks Deskripsi}

Berdasarkan Gambar 4.1 di atas, secara jelas tergambar bahwa terdapat peningkatan kemampuan membaca dari sebelum dilakukannya penelitian tindakan yakni ketuntasan yang dicapai hanya sebesar $61 \%$. Setelah dilakukan penelitian tindakan kelas dengan penerapan pembelajaran STAD berbantuan media Gambar, capaian hasil belajar siswa dalam hal ini kemampuan membaca siklus I dengan nilai rata-rata klasikal 70,29 ketuntasan $74 \%$, dan nilai rata-rata klasikal pada siklus II adalah 73,41 ketuntasan $83 \%$.

\section{SIMPULAN DAN SARAN}

Penelitian tindakan kelas yang dilakukan dengan penerapan pembelajaran Student Teams Achievement Divisions (STAD) berbantuan Media Gambar. Adapun simpulan yang di ambil adalah sebagai berikut:

1) Aktivitas/sikap siswa selama mengikuti kegiatan belajar mengajar di kelas Pada siklus I dan siklus II berada pada kriteria baik. 
2) Hasil evaluasi pembelajaran kemampuan siswa dalam membaca teks deskripsi sederhana melalui penerapan pembelajaran STAD berbantuan media gambar pada siklus I diperoleh nilai rata-rata klasikal 70,29 ketuntasan $74 \%$, dan nilai rata-rata klasikal pada siklus II adalah 73,41 ketuntasan 83\%. Hal ini bermakna bahwa penerapan pembelajaran STAD berbantuan media gambar dapat meningkatkan kemampuan membaca teks deskripsi sederhana siswa kelas I Semester II SD Negeri 9 Peguyangan.

Sehubungan dengan simpulan diatas, maka dapat dikemukakan beberapa saran sebagai berikut:

1) Guru harus selektif dalam memilih metode/strategi pembelajaran agar metode yang dipilih dapat bermanfaat untuk mengasah daya pikir siswa sesuai dengan minat dan bakatnya, serta semangat dalam belajar membaca.

2) Hasil penelitian ini dapat dijadikan sebagai acuan untuk penelitian yang sejenis. Sebaiknya penelitian selanjutnya dapat mengombinasikan metode pembelajaran kooperatif dengan media belajar lainnya agar siswa mencapai hasil belajar yang optimal dan memuaskan.

\section{DAFTAR PUSTAKA}

Chaplin, C.P. 1997. Kamus Lengkap Psikologi. Jakarta: Raja Grafindo Pustaka

Damayanti, Yanti. 2008. Penerapan Model Pembelajaran Kooperatif Two Stay Two Stray (Tsts) Menggunakan Cd Pembelajaran. Tesis.Semarang: Program Pasca Sarjana Program Studi Penidikan IPA Universitas Negeri Semarang

Desmita, R. 2008. Psikologi Perkembangan. Bandung: PT.Remaja Rosdakarya

Djago Tarigan, 1997. Pendidikan dan Bahasa Sastra Indonesia di Kelas Rendah. Jakarta: Universitas Terbuka.

Handayani, Fitri. 2009. Pembelajaran Kooperatif Tipe Team Game Tournament (TGT) untuk Meningkatkan Hasil BelajarSiswa Kelas VII SMP Negeri I Purwodadi Kabupaten Pasuruan Pada Materi Keragaman BentukMuka Bumi. Tesis. Malang: Program Pascasarjana Universitas Negeri Malang

Mihtahul Huda. 2009. Model-model Pengajaran dan Pembelajaran. Yogyakarta: Pustaka Pelajar.

Renawati, Diah S.Pd. 2011. Penerapan Model Pembelajaran Membaca dan Menulis Untuk Meningkatkan Minat Dan Hasil Belajar Bahasa Indonesia Pada Siswa Kelas III 
Semester II SDN Sumber Kejayan 03 Kecamatan Mayang Kabupaten Jember. PTK. Pemerintah Kabupaten Jember: Dinas Pendidikan Kabupaten Jember.

Sarwiji Suwandi. 2008. Penelitian Tindakan Kelas dan Penulisan Karya Ilmiah.Surakarta : Panitia Sertifikasi Guru.

Sugiyono. 2013. Metode Penelitian Bisnis. Bandung: Alfabeta

Suryadi. 2010. Panduan Penelitian Tindakan Kelas. Yogyakarta: Diva Press

Tarigan, Henry Guntur. 2008. Membaca Sebagai Suatu Keterampilan Berbahasa. Bandung: Angkasa. 